\title{
Reflection on Public Physical Education in Chinese Colleges and Universities
}

\author{
Xiaosong Zeng \\ Department of P.E. \\ Shenzhen University \\ Shenzhen, China \\ 66608936@qq.com
}

\author{
Xueyun Shao \\ Golf College \\ Shenzhen University \\ Shenzhen, China \\ shaoxy@szu.edu.cn
}

\begin{abstract}
The main object of this paper is to build the information management system based on integration and development of college sports resources, it also explores on how to integrate college sports resources development by means of information, and how to make it more efficient and effective. The author attempts to probe college sports resources' development and management from the angle of theory and practice, understanding and integration advantages of characteristics of college sports resources through concept of Digital Campus at the same time. The development strategy is put forwarded to from the theoretical and applied research angle as well, providing the basis for decision-making and management of the development of colleges and universities public sports.
\end{abstract}

Keywords-colleges and universities; public physical education; education; digital campus

\section{INTRODUCTION}

In recent years, the physical fitness of students has become the focus of the whole society. The CPC Central Committee and the State Council's Decision on Deepening Education Reform and Promoting Quality Education Decision pointed out: "Health body is the basic premise of youth to service to motherland and citizen, and it is the embodiment of Chinese nation's vitality. School education should establish the guiding ideology of health first, strengthen physical education, enable students to master the basic motor skills, develop good habits of physical exercise." Health first is the need to implement China's educational policy, to adapt to the needs of educational law, to meet the need of physiology \& psychology of teenagers.

\section{THE SIGNIFICANCE OF PUBLIC PHYSICAL EDUCATION IN CHINESE COLLEGES AND UNIVEISITIES}

National Conference on School Sports was held the first time on December 23, 2006. In 2007, The CPC Central Committee and the State Council's Decision on Deepening Education Reform and Promoting Quality Education Decision was issued by the Ministry of education, the State Sports General Administration and the Communist Youth League Central Committee (2007), in which indicated that improving the health of young people and promoting the healthy growth of young people, is of great importance to the relationship between the state and the nation's future. Considering health first as one of the strategic objectives for the implementation of quality education reflects the party and the country pay highly attention to promote young people's physical and mental health. This idea provides a solid theoretical basis for the reform of college physical education. University physical education links up with society, and it is the transfer station of family sports and community sports, which put forward even higher requirements to the public physical education in colleges and universities. The modern physical education course in colleges and universities must adapt to the needs of social development and students' individual development needs through constantly reform and update.

With the gradual deepening of China's reform openingup process and the rapid development of economic, cultural and other fields, Chinese society's demand for sports and the demands of school physical education has also undergone a fundamental change. Lifelong sports, sports living, leisure, entertainment and industrialization, have raised strong requirements on the reform of school physical education.

As the guidance documents of public physical education curriculum in China higher education reform and development in new century, Teaching Guidance Outline of National Higher Education Institution Sports Curriculum (hereinafter referred to as the Guidance), was issued ten years ago by the Ministry of Education in 2002. Followed the Guidance spirit, many colleges and universities are actively reform and try in these ten years. Sports course in college public physical education has changed profoundly. Colleges and universities across the country actively implement the Guidance spirit, accelerate the pace of reform of physical education curriculum, establish the teaching idea adapting to the new curriculum, innovate college sports curriculum model, integrate sports resources in colleges and universities, strengthen college students to accept the sports education actively, to participate in sports activities consciously, and establish the sustainable development strategy to the concept of lifelong education. We have obtained a lot of achievement in ten years time of implementing the Guidance; however, there are also some problems at the same time. Exploring solutions to various problems in the implementation process of college physical education courses helps to promote the further our college physical education curriculum reform and development road. 


\section{The Problems of PbUlic PyHSiCAl EdUCATION IN CHINESE COLLEGES AND UNIVEISITIES}

\section{A. Imperfection of Public Physical Education Courses Setup in Colleges and Universities of Our Ccountry}

University is the key stage for students to cultivate interests in sports and lifelong physical exercise habit. Whether carrying out physical education successfully or not really has relationship with students' lifelong sports consciousness and the formation of exercise habit. It is selfevident that physical education is important to college students[1]. When in school, students not only learn sports knowledge, technology and skills through schedule arrangement in physical education institute, but also cultivate sports interest, sports ability, raise sports habit from school sports culture atmosphere and various sports activities and sports practice organized by universities, the unrevealed value and idea grows as well. This kind of dark humor (metaphor) aspects of teaching, value, idea, attitude, influence character by environment effects should not be underestimated.

But public physical education curriculum in our universities is not perfect, rate with sports class is low in higher grade of university (including graduate), especially in physical education postgraduate classes, opened only in a few schools. Sports curriculum in low grade is relatively perfect, but there exists phenomenon of compression class.

\section{B. Public Sports Courses inColleges and Universities of Our Country is Still Not Open Completely}

Modern sports curriculum emphasizes the individualization and diversification of curriculum, so that students have the right to choose learning content and development direction according to their ability and interest. We should give students more space and flexibility to organize and control their own learning. Based on the diversity respect for students' development, it is declared that we should meet the diverse needs of students' development, make sports become important content of college students healthy and happy leisure time. The setting up mode of public sports curriculum in institutions in China are being or have broken the traditional classroom teaching mode, three independent, i.e. the independent choice of sports items, teachers and class time has become development direction.

Nevertheless, there are schools students still did not have the right to choose. They learn the curriculum in fully accordance with the school arrangement. In addition, because of greatly increased number of colleges and universities students, sports development expansion, students average area reduction, and the limitation of teachers and other resources have considered as important resistance of school three independent course modes. To open course completely, it also need schools further efforts to overcome a lot of exist obstruction.
C. There are Many Problems in the Organization, Management System and Method in Extra-curricular Sports Activities of Colleges and Universities in Our Country

The extracurricular activities in colleges and universities is an important part of school sports, which is a continuation and supplement of school physical education curriculum and an important way to achieve the objective of school physical education. Because of flexible and diverse forms of organization, interesting contents, free selective of the extracurricular sports activities, it has significant meaning in cultivation of students' interests in sports, forge students' sports consciousness, develop students' personality, improve sports ability, enhance students' physical health, improve the ability to adapt to society, consciously develop the habit of physical exercise and all-round development of students' overall quality, and laid solid foundation for the establishment of lifelong physical education objectives. The CPC Central Committee and the State Council's Decision on Deepening Education Reform and Promoting Quality Education Decision pointed out that high education institution should strengthen the management of physical education courses, integrate the extracurricular sports activities into the daily teaching plans of the school, so that each student could participate in the extracurricular physical exercise at least three times a week.

The education administrative departments at all levels should put forward specific requirements for exercise about an hour every day and do a good job in the implementation. But form of organization of students' extracurricular sports activities in universities of our country is too single. There are many problems in the management system and management methods, which need further reform and strengthen, the participation rate and the physical training time of college students extracurricular sports activities is low at large, especially for girls.

\section{Some of Colleges Pay Insufficient Attention to Physical Health Survey}

The implement of Student Physique Healthy Standard jointly formulated by the Ministry of education and the State Sports General Administration lead the school has an objective standard of students' physical health evaluation. And has an important influence on the modern school physical education research, evaluation of student physique health, physical training effect evaluation, the evaluation of physical education teaching etc..

Some colleges and universities do not take physical health survey seriously enough, and the accuracy of data needs to be confirming again. As for physical health standard, it also has deviation and needs further perfection. The propaganda and education of physical health test education function, guiding function and feedback function in some colleges and universities is not enough, to some extent, which affects its implement[2]. Meanwhile, it is necessary to construct comprehensive evaluation of health system for college students eventually, combined with the physical characteristics of college students and observation college 
students' physical exercise behavior. Such practice will reflect the school education for students of individual service and humanism, and truly achieve effect of improve students' health by survey to promote the practice. According to the health belief model and related theoretical research, health warning analysis system will be established based on physical health test data analysis and health forecast. In the implementation of physical health test, warning health tips are analyzed and generated according to test data of individual students. The results of warning will promote students' attention on the physical health. The early warning mechanism theory construction provides key information to individual health improvement. It leads students have psychological effect of urgency healthy sense, thereby promoting students' attention to the health and will spend more time in exercise. At the same time, physical health warning and sports course are combined. Experiment curriculum of physical health and sports combination is under ongoing now. The various elements of this course is been designed innovatively, fully implement the health first guiding ideology.

\section{E. Sports Information Rresources in Colleges and Universities Need to be Integrated}

With the development of information society, the internet and multimedia technology has become an important means to change the way of people's life quality and life increasingly. College students have used campus network for learning or assisting learning much. Online searching for information, accessing to various resources, seeking help via forums and instant communication tool has become an important part of learning life of university students.

It has become an important research topic in the teaching reform and practice of modern sports that sports teaching in colleges and universities how to adapt to the development of the times, taking the advantage of network education, combining network education and physical education teaching organically so that teaching quality of physical education will be improved. Department of physical education in colleges and universities has set up sports sites, but most of them do it only for the purpose of network[3]. They do little research on physical education teaching resources, which causes disunity in data specification and standard, scattered sports teaching resources. Information can not be shared and forms an information island, so it needs integrated urgently. The traditional sports teaching website could not adapt to the rapid development of school physical education teaching, it is urgent need to construct a new information resource sharing model to solve problems in the process of informatization.

\section{F. Management Methods of College Sports Stadium in China is Relatively Backward}

The basic function of university stadium is to ensure college's PE teaching and service to students' extracurricular activities. The sports facility resources in colleges and universities is an important material guarantee for students involving in sports. Sports resources should be used effectively by better service for existing students. By doing that it will finally achieve the maximum utilization of resources and avoid waste $\&$ idle venues resources, and fully guarantee the students extracurricular sports activities. But the venue management methods of college sports in China is relatively backward, management methods of sports venues, the feasibility of science, rationality, practicability need to be improved. Sports venues management of colleges and universities in China is in a spontaneous low level and low efficiency status, resulting in low sports venues and facilities utilization rate. A large number of stadiums have the serious phenomenon which in the idle state.

At present, the guiding ideology of sports facilities construction in colleges and universities is unilateral, emphasizing standardization and service for competitive sports, lacking of standardized stadium management phenomenon. In addition, the basic functions of school stadium that guaranteeing the teaching tasks and satisfy college students extracurricular sports activities has not attracted the deserving attention. The limited stadium can not meet the basic needs of college students' after-school sports training. The opening to public with money policy school seriously affected the normal use of the stadium for college students extracurricular exercise.

\section{G. Lack of College Sports Resources}

College sports resources are the basic elements of college physical education teaching work and organizations activities. It is also an important symbol of the development of college physical education. But the quantity, quality, scarce of allocation of college sports resources result the contradiction between the increasing number of sports student and the lack of resources in colleges and universities more and more obviously. Therefore, how to effectively integrate the university sports resources and rational development? How to benefit from the limited resources and optimize the allocation and utilization of the limited resources? All of these questions have become great practical significant research for the reform of college physical education whether they could adapt to social development need and promote their innovation or not.

\section{CONCLUSION}

21 st century is the era of information and knowledge, education informationization has become an important symbol to measure the education modernization level and the comprehensive strength. Many universities have built modern information management network system, i.e. Digital Campus. As an important part of college work, college sports also involved as one's unshirkable responsibility. The main object of this paper is to build the information management system based on integration and development of college sports resources, exploring how to integrate college sports resources development by means of information, and how to make it more efficient and effective. The author also attempts to probe college sports resources' development and management from the angle of theory and practice, understanding and integration advantages of characteristics of college sports resources through concept of Digital Campus. The development strategy is also put 
forwarded to from the theoretical and applied research angle, providing the basis for decision-making and management of the development of colleges and universities public sports.

\section{ACKNOWLEDGMENT}

This paper is financially supported by National Social Science Foundation of China (Grant No. 13CTY034), and Foundation for Distinguished Young Talents in Higher Education of Guangdong, China (Grant No. 2012WYM_0117).

\section{CORRESPONDING AUTHOR}

Xueyun Shao, shaoxy@szu.edu.cn, 86+13510198798.

\section{REFERENCES}

[1] P. Liang, "An approach to evaluating the college public physical education class teaching quality with linguistic information," Journal of Convergence Information Technology, vol. 7, pp. 129-135, May 2012.

[2] F. Jiafu, "The study of stadium industrial development status and countermeasures of physical education institute,"Advanced Materials Research, vol. 472-475, pp. 1275-1278, 2012.

[3] P. Constantin, "New types of education - Premises for formation of physical education and sports teachers," International Conference on Education and Educational Technologies - Proceedings, pp. 352$360,2010$. 